\title{
Quality and post-harvest life organic pomegranate 'Molar' produced in Paraiba semiarid
}

\section{Qualidade e vida útil pós-colheita de romã 'Molar' orgânica produzida no semi-árido paraibano}

\author{
Isana Maria Brito Roque Silva ${ }^{1}$; Railene Hérica Carlos Rocha ${ }^{2 *}$; \\ Helton de Souza Silva ${ }^{3}$; Inácia dos Santos Moreira \\ Francisco de Assis de Sousa ${ }^{3}$; Emanoela Pereira de Paiva ${ }^{5}$
}

\begin{abstract}
A pomegranate is a species of wide use, especially due to the medicinal importance, where the fruits were appreciated around the world. The marketing of pomegranate has increased and aroused the interest of fruit producers in Brazil, however, knowledge of the quality and commercial viability of the fruit in natura is incipient. In this sense, this study aimed to determine the quality and postharvest life of pomegranates 'Molar' stored at $27^{\circ} \mathrm{C}$ and $28 \% \mathrm{RH}$. Was used in a completely randomized design with four replications, each replicate consisting of five fruits and seven evaluation periods. At each assessment time $0,3,6,9,12,15$ and 18 days of storage after harvest is conducted through analysis of samples of fruits $(n=20)$, obtained at random from the container type plastic boxes, condition where the total of 140 fruit was stored in the experiment. In each evaluation period was assessed longitudinal and transverse length, fresh weight loss, weight of arils, juice volume, seed mass, shell mass, soluble solids (SS), titratable acidity (TA), $\mathrm{pH}, \mathrm{SS} / \mathrm{TA}$, vitamin $\mathrm{C}$ and extern and interns appearance. Pomegranate 'Molar' produced in an organic system in semiarid from Paraíba is classified as sweet, with low acidity, less than $0,75 \%$ citric acid and soluble solid between 12 and $15 \%$. The storage of fruits at $27^{\circ} \mathrm{C}, 28 \%$ RH up to six days maintains appropriate biometric, physical-chemical and visual characteristics for the fresh fruit market. The storage of fruits at $27^{\circ} \mathrm{C}, 28 \% \mathrm{RH}$ for 18 days provocation dehydration of the skin, but not affect the quality or yield of juice extracted from the arils.
\end{abstract}

Key words: Punica granatum L., conservation, marketing, in nature consumption

\section{Resumo}

A romãzeira é uma espécie de ampla utilização, especialmente devido à importância medicinal, sendo os frutos apreciados no Mundo todo. A comercialização de romã tem aumentado e despertado o interesse de fruticultores no Brasil, porém, o conhecimento da qualidade e da viabilidade comercial do fruto 'in natura' é incipiente. Neste sentido, objetivou-se neste trabalho determinar a qualidade e a vida útil pós-colheita da romã 'Molar' armazenada a $27^{\circ} \mathrm{C}$ e $28 \%$ UR. Utilizou-se o delineamento inteiramente

${ }_{1}$ M.e em Sistemas Agroindustriais, Prof ${ }^{\text {a }}$ do Instituto Centro de Ensino Tecnológico, CENTEC, Juazeiro do Norte, CE, Brasil. E-mail: isamarbrito@gmail.com

${ }^{2} \mathrm{Dr}^{\mathrm{a}}$ em Fitotecnia, Prof ${ }^{\mathrm{a}}$, Universidade Federal de Campina Grande, UFCG, Pombal, PB, Brasil. E-mail: raileneherica@ccta. ufcg.edu.br

3 Eng ${ }^{\text {os }}$ Agr $^{\text {rs }}$, UFCG, Pombal, PB, Brasil. E-mail: heltonssilva@gmail.com; franciscoufcg@gmail.com

4 Tecnóloga em Alimentos, Discente do Curso de Doutorado do Programa de Pós-Graduação em Engenharia Agrícola, UFCG, Campina Grande, PB. E-mail: inaciamoreira@ymail.com

5 Eng $^{\mathrm{a}} \mathrm{Agr}^{\mathrm{a}}$, Discente do Curso de Doutorado em Fitotecnia, Universidade Federal Rural do Semi-Árido, UFERSA, Mossoró, RN, Brasil. E-mail: emanuelappaiva@hotmail.com

* Author for correspondence 
casualizado, com quatro repetições, sendo cada repetição constituída por cinco frutos, e sete épocas de avaliação. Em cada época de avaliação 0, 3, 6, 9, 12, 15 e 18 dias de armazenamento após a colheita, realizaram-se análises através de amostragens de frutos $(n=20)$, obtidos ao acaso de caixas plásticas do tipo contentores, condição na qual o total de 140 frutos do experimento foi armazenado. Em cada época de avaliação determinou-se comprimento longitudinal e transversal, perda de massa fresca, massa dos arilos, volume de suco, massa das sementes, massa da casca, sólidos solúveis (SS), acidez titulável (AT), $\mathrm{pH}$, relação SS/AT, vitamina $\mathrm{C}$ e aparência externa e interna. A romã 'Molar' produzida em sistema orgânico no semi-árido paraibano é classificada como doce, com baixa acidez, inferior a 0,75\% de ácido cítrico e sólido solúveis entre 12 e $15 \%$. O armazenamento dos frutos a $27^{\circ} \mathrm{C}, 28 \%$ UR até seis dias mantém as características biométricas, físico-químicas e visuais apropriadas para a comercialização in natura. $\mathrm{O}$ armazenamento dos frutos a $27^{\circ} \mathrm{C}, 28 \%$ UR por 18 dias propociona intesa desidratação da casca, porém não prejudica a qualidade nem o rendimento de suco extraído dos arilos.

Palavras-chave: Punica granatum L., conservação, comercialização, consumo 'in natura'

\section{Introduction}

Pomegranate (Punica granatum L.) is a branched, ligneous shrub native to the region spanning from Iran to the Himalayas in northwestern India. It has been cultivated for a long time throughout the Mediterranean region in Asia, the Americas, Africa, and Europe, with extensive cultivation in the arid and semi-arid regions worldwide (AL-MAIMAN; AHMAD, 2002). In Brazil, pomegranate is commercially cultivated in the states of São Paulo, Bahia, Paraíba, and Ceará, in which the best time for sale of the fruit in natura is the period from November to December, when the demand for the fruit can increase for up to $30 \%$ and the price up to 28\% per kilogram (FRAGA, 2013).

Pomegranate fruits have been traditionally used to treat various health problems, mainly gastrointestinal. Anthocyanins in the pomegranate fruit have shown elevated antioxidant activity, higher than vitamin $\mathrm{E}$ ( $\alpha$-tocopherol), vitamin $\mathrm{C}$ (ascorbic acid), and $\beta$-carotene. Additionally, antioxidant activity of pomegranate juice is three times higher than that of green tea or red wine and therefore has been used to treat ulcers, earaches, dysentery, and leprosy (JADON et al., 2012). Beyond its medicinal importance, pomegranate is widely used in the food industry in the production of juices, jams, food flavorings, and color additives.

Hence, the use of technologies for preservation of the fruit 'in natura' is fundamental for its commercial exploitation and for winning new markets. Classified as a non-climacteric fruit, pomegranate has low respiration rates during storage. At $5^{\circ} \mathrm{C}$, its respiration rate ranges from 4 to $8 \mathrm{mg} \mathrm{CO} \mathrm{kg}^{-1} \cdot \mathrm{h}^{-1}$, at $10^{\circ} \mathrm{C}$ it ranges from 8 to $16 \mathrm{mg}$ $\mathrm{CO}_{2} \mathrm{~kg}^{-1} \cdot \mathrm{h}^{-1}$, and at $20^{\circ} \mathrm{C}$ it ranges from 16 to $32 \mathrm{mg}$ $\mathrm{CO}_{2} \mathrm{~kg}^{-1} \cdot \mathrm{h}^{-1}$ (CRISOSTO et al., 1996).

When intended for the 'in natura' market, the most valued criterion in the evaluation of fruit quality is its external appearance. In pomegranate, some of the problems during its sale are dryness and presence of skin blemishes, which impair fruit appearance and quality. Loss of quality and consequently loss of commercial value is the result of elevated water loss. The increase in storage temperature raises fruit's respiration rate (CRISOSTO et al., 1996), contributing to the increase in water loss and alteration of fruit's fresh mass and shape, characteristics that can be important for proper fitting of fruits inside the packages and that affect its market value given that many fruits are sold by weight.

There are pomegranate varieties that produce highly acidic fruits, considered acidic pomegranates, with acidity level above $2 \%$; bittersweet varieties, with acidity level between $1 \%$ and $2 \%$; and varieties that produce low acidic fruits, Considered sweet pomegranates, with acidity level less than $1 \%$ (ONUR; KASKA, 1985). Citric acid is predominant in acidic varieties, whereas in sweet varieties, acidity results from balanced quantities of citric and 
malic acid, or in some cases, predominantly from malic acid (POYRAZOGLU et al., 2002; OZGEN et al., 2008).

In comparison with other fruits, pomegranate juice has low ascorbic acid content, ranging from 0.49 to $30 \mathrm{mg} 100 \mathrm{~g}^{-1}$, depending on the variety (KÜPPER, 1995). Ascorbic acid levels decrease during the first stages of fruit development and remain more or less stable in the final stages of maturation, with values between 10 and 36 $\mathrm{mg} / 100 \mathrm{~g}$, depending on the pomegranate variety (KULKARNI; ARADHYA, 2005; SAYYARI et al., 2010).

During the maturation of pomegranate, sugar accumulates and total acidity reduces in the arils (KULKARNI; ARADHYA, 2005). The soluble solids vary in different pomegranate varieties, with certain Spanish varieties containing 12.36-16.32\% of soluble solids (SADEGHI, 2010). In Turkish varieties, the total minimum of soluble solids is $16 \%$ and the maximum is $19 \%$ (POYLAZOGLU et al., 2002; SADEGHI, 2010). The variety Taief from Saudi Arabia contains 16.9\%, and Portugal's variety Asaria contains $14.5 \%$ of soluble solids (MIGUEL et al., 2004; SADEGHI, 2010).

Consequently, this work aimed to determine, through biometric, visual, and physicochemical evaluations, the postharvest quality and storage life of the pomegranate variety Molar stored under ambient conditions $\left(27^{\circ} \mathrm{C}\right.$ and $28 \%$ relative humidity $[\mathrm{RH}])$.

\section{Materials and Methods}

The fruits were acquired from the Águas de Tamanduá farm, localized in Várzeas de Sousa, Sousa-PB, located $30 \mathrm{~km}$ from the Pombal-PB municipality. The 30 -ha area of the property that is cultivated with Molar pomegranate is three years old, and it is managed under organic production system that has been certified by the Certification Association Biodynamic Institute (Instituto Biodinâmico, IBD), Law 10.831 .
The fruits were harvested in the morning at commercial maturity stage, which on average corresponds to four months following anthesis. Uniform standards of size, color, and absence of defects were established as criteria for harvesting. Next, the fruits were carefully placed in plastic crates with capacity of 40 kilograms (PN 40), internally lined with newspaper. The fruits were then transported to the Food Analysis laboratory of the Federal University of Campina Grande, Pombal Campus, PB.

In the laboratory, the fruits that did not comply with the quality standards established at the time of harvest were eliminated. The fruits were then sanitized by washing in a solution containing $1 \%$ neutral detergent and after rinsing, they were immersed in a 100 ppm active sodium hypochlorite solution for $5 \mathrm{~min}$. After air-drying, the pomegranates were placed in clean plastic containers and kept in a room that simulated the temperature and moisture conditions during sale at the local market $\left(27 \pm 5^{\circ} \mathrm{C}\right.$ and $28 \pm 10 \% \mathrm{RH})$.

The experiment was organized in a completely randomized designed with four repetitions, each repetition consisting of five fruits and seven evaluation times. A total of 160 fruits were used in the biometric, visual, and physicochemical evaluations carried out periodically at $0,3,6,9,12$, 15 , and 18 days of storage. A sample of 20 fruits (n $=20$ ) was used for biometric evaluations, and the same fruits were kept throughout the storage period. For identification in the containers, the fruits were pen marked and, after each periodic evaluation, returned to their crates (PN 40). Twenty randomly sampled fruits $(n=20)$ were taken for destructive analysis, but arbitrarily obtained marked fruits were returned to their original crates.

Biometric analysis was performed on each fruit by determining the longitudinal and transverse length, fresh mass, aril mass, juice content, seed mass, and peel mass. The results were expressed as a percentage $(\%)$, taking into account the difference 
between the values registered at the day of harvest and those obtained periodically in the evaluations during storage. To evaluate the longitudinal length, the fruits were measured individually from apex to basis, and for the transverse length, the measurements were done at the equatorial section, using for both a digital caliper. To determine the fresh mass, the fruits were weighed individually on an electronic precision weighing scale (0.0001 g). Aril mass was determined by gravimetric analysis on an analytical precision weighing scale after extraction of the fruit. Juice content was determined after grinding the arils in a plastic bag, and the total volume obtained from each fruit was measured in a measuring cylinder. Seed mass was determined after the extraction of the juice through gravimetry on an analytical precision weighing scale. Peel mass was also determined via gravimetry on an analytical precision weighing scale.

Visual analysis was carried out by characterizing the external and internal appearance, and the final values were obtained by averaging the scores assigned by three previously trained examiners. The scores ranged between 5 and 0 , according to the severity of the defect. An external appearance score of 5 was attributed to fruits with less than $1 \%$ of dents, absence of blemishes, and absence of microorganism attacks; score of 4 was assigned when $1-10 \%$ of the fruit was blemished or dry; score of 3 when $11-30 \%$ of the fruit was dry or had minor blemishes; score of 2 when $31-50 \%$ of the fruit was dry or had moderate blemishes; score of 1 , when $51-60 \%$ of the fruit was dry and had severe blemishes or was attacked by microorganisms; score of 0 , dry, very severe blemishes or widespread attack by microorganism. In the assessment of the internal appearance, a score of 5 was attributed to fruits without loose seeds; score of 4 , fruits with $1-10 \%$ of seeds loose and altered aril color; score of 3 , fruits with $11-30 \%$ of loose seeds, alterations in aril color, and microorganism traces; score of 2 , fruits with $31-50 \%$ of loose seeds, alterations in aril color, and presence of microorganisms; score of 1 , fruits with $51-60 \%$ of loose seeds, alterations in aril color, and severe microorganism attack; score of 0 , fruits with over $60 \%$ of loose seeds, alterations in aril color, and widespread microorganism attack.

The physical and chemical analyses included soluble solids (SS, \%), determined directly from the homogenized juice using a digital refractometer (PR-100, Palette series, Atago Co., Ltd., Tokyo, Japan) with automatic temperature compensation; titratable acidity (TA, \% citric acid), determined in triplicate by adding $45 \mathrm{~mL}$ of distilled water and three drops of $1 \%$ alcoholic phenolphthalein to $5 \mathrm{ml}$ of juice aliquot, followed by titration with previously standardized $0.1 \mathrm{~N} \mathrm{NaOH}$ solution (INSTITUTO ADOLFO LUTZ, 2008); $\mathrm{pH}$ (at $25^{\circ} \mathrm{C}$ ), determined directly from the juice using a digital glass electrode potentiometer, calibrated with $\mathrm{pH} 4.0$ and $\mathrm{pH} 7.0$ buffer solutions; SS/TA ratio, determined as the ratio between the two traits; vitamin $\mathrm{C}$ content ( $\mathrm{mg}$ $100 \mathrm{~g}^{-1}$ of juice), measured in triplicate using $1 \mathrm{~g}$ of juice diluted in $49 \mathrm{~mL}$ of oxalic acid, followed by titration with Tilman solution (INSTITUTO ADOLFO LUTZ, 2008).

The data were submitted to the analysis of variance, and a regression analysis of the quantitative characteristics was performed. The linear and nonlinear models were chosen based on the potential to explain the biological phenomenon in question using the determination coefficient and the level of significance of the regression coefficients. Visual analysis was performed using Tukey's test at 5\% probability and presented in bar graphs.

\section{Results and Discussion}

There was a statistically significant difference at a probability level of $1 \%$ for the biometric, physicochemical, and visual variables analyzed for the Molar pomegranate, in relation to the number of days in storage, under ambient conditions. 


\section{Biometric characteristics}

The pomegranate's fresh mass linearly decreased as the storage time progressed (Figure 1A); more than $20 \%$ loss of fresh mass was observed already on the third day of storage and a loss of over $30 \%$ by day 18 (Figure 1B). In accordance with the decrease in fruit's fresh mass and the increase in mass loss, fresh mass of the peel per fruit linearly decreased (Figure 1C). Similar to the values shown in this study, a variation of $40-45 \%$ of peel in relation to the pomegranate's total mass was observed by Serrano (2012).

Figure 1. Fresh fruit mass (A), loss of weight (B) mass ratio of peel / fruit mass (C), mass ratio of seeds and arils / fruit mass (D) in pomegranate 'Molar' stored under ambient conditions $\left(27^{\circ} \mathrm{C}, 28 \% \mathrm{RH}\right)$.
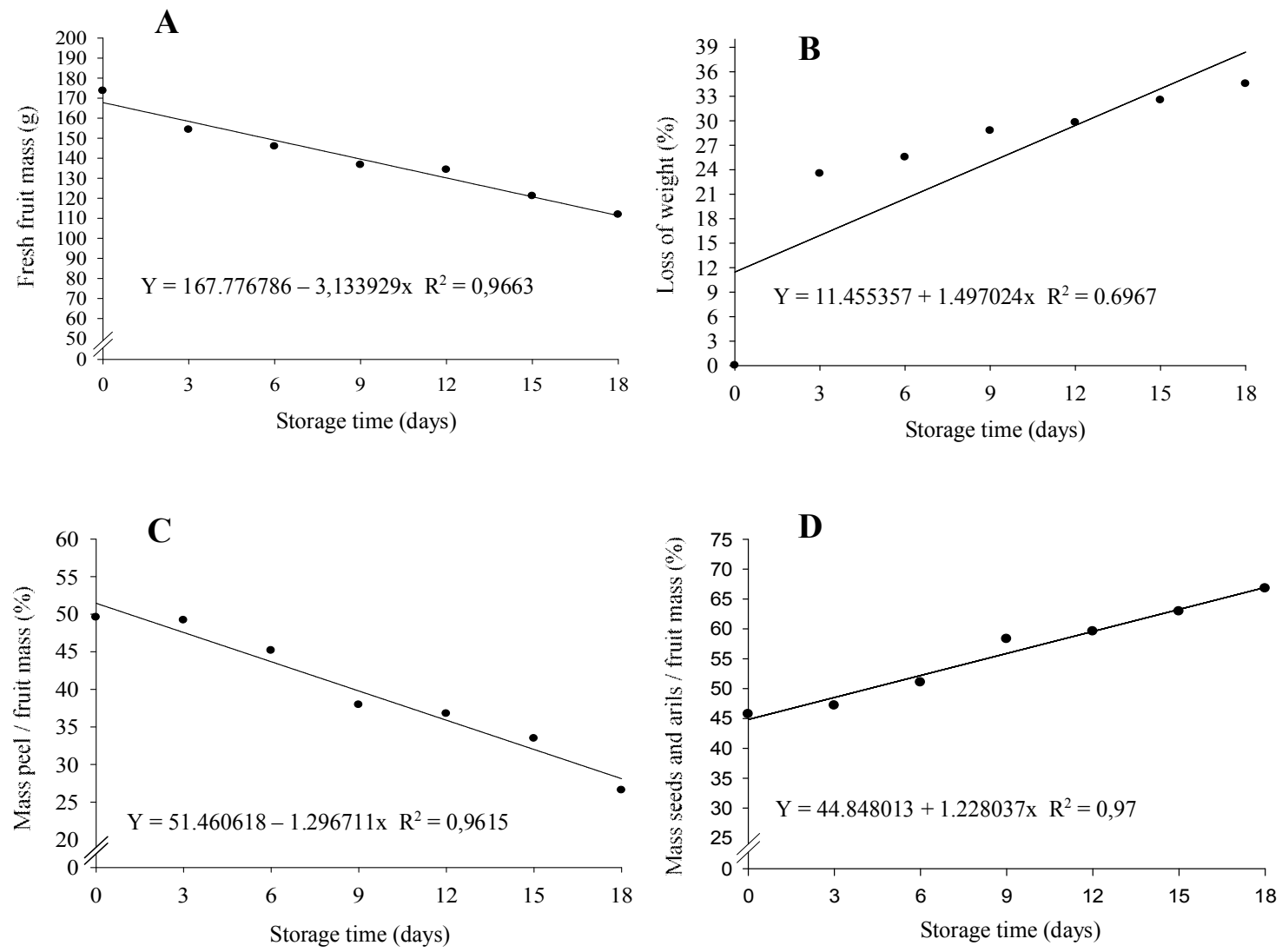

The ratio of seed and aril mass to fruit mass increased during storage (Figure 1D). This behavior was attributed to the increase in fruit mass loss as storage time progressed, marked especially by elevated loss in peel mass. Thus, storing the fruits at $27^{\circ} \mathrm{C}$ and $28 \% \mathrm{RH}$ for 18 days caused intense peel desiccation; however, it also created a barrier against loss of the fruit's internal moisture. According to a study performed by Quiroz (2009), there is less mass in pomegranate varieties with pink arils, such as Molar de Elche, in which variations of $55-60 \%$

of seeds in relation to fruit weight were observed. Sadegi (2010) found that seeds represented 58$78 \%$ of the fruit weight in two indigenous varieties, showing that varieties with lower seed per fruit ratio result in lower juice yield.

Regarding their weight and size, pomegranates are classified in four groups: small (150-200 $\mathrm{g}$ and 65-74-mm diameter), medium (201-300 g and 7585-mm diameter), large (301-400 $\mathrm{g}$ and 85-94-mm diameter), and extra large (401-500 g and 95-104- 
mm diameter) (ONUR; KASKA, 1985). Given this classification, the pomegranates used in the present study were categorized as small, weighing less than $200 \mathrm{~g}$ and being less than $74 \mathrm{~mm}$ in diameter.

There was also a linear increase in the seed mass/fruit mass ratio during storage (Figure
2A). Similarly, the juice volume/fruit mass ratio increased over time (Figure 2B). These changes were attributed to the decrease in the fruit's fresh mass, which was significant after 18 days in storage. Morphologically, alterations in shape and tissue turgidity were observed, whereas the integrity of the seeds and the aril's succulence remained unchanged.

Figure 2. Relative mass of seeds / fruit mass (A), relative volume of juice / fruit mass (B), reduced axial fruit diameter / longitudinal diameter of the fruit at harvest (C), reducing the transverse diameter of the fruit / transverse diameter of the fruit at harvest (D) in pomegranate 'Molar' stored under ambient conditions $\left(27^{\circ} \mathrm{C}, 28 \% \mathrm{RH}\right)$.
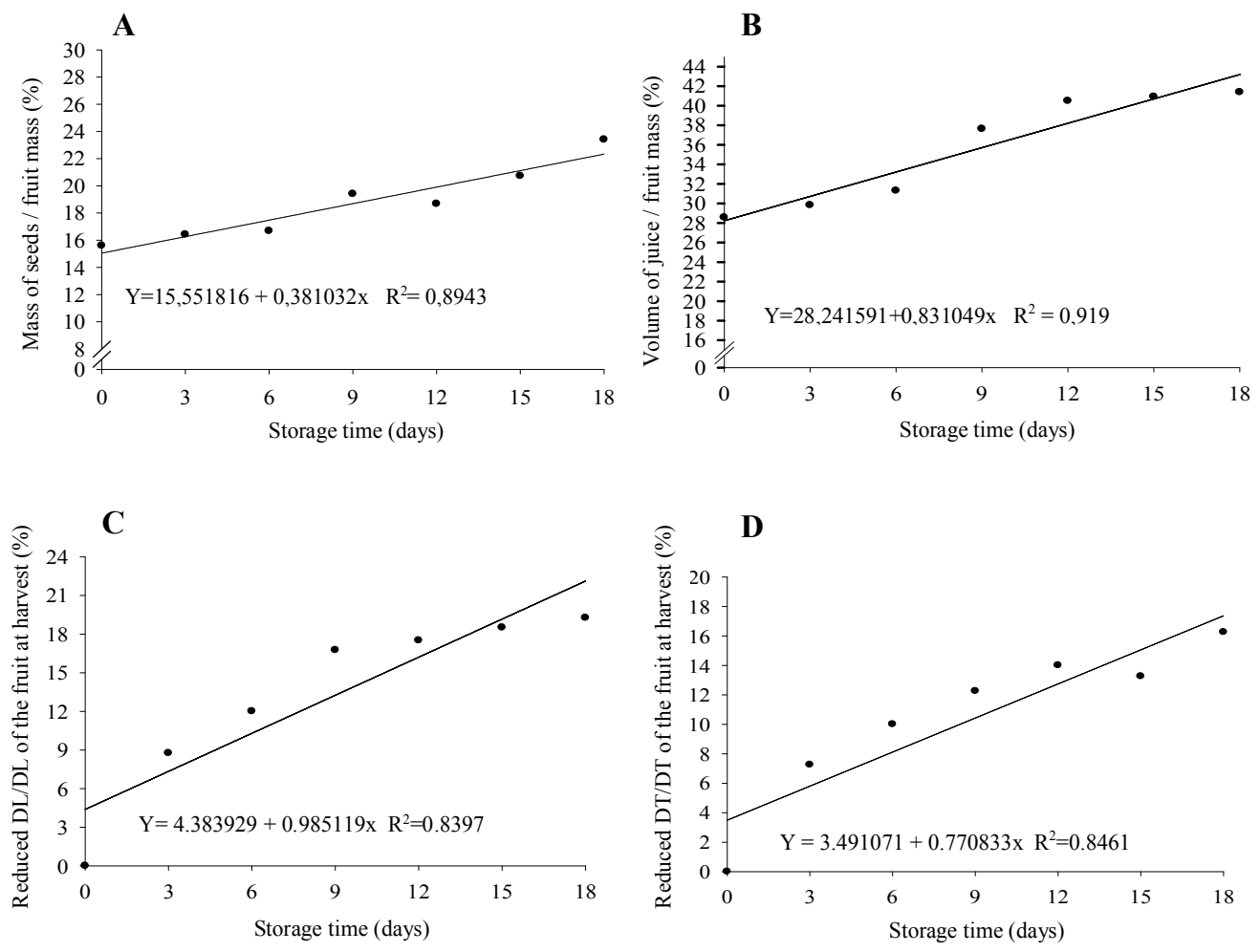

At day zero, juice volume to fruit mass ratio was $28 \%$. This ratio increased to more than $40 \%$ by the end of the storage period due to changes in the peel from the state of high turgidity, at the start of storage period, to highly desiccated and dry state, when it acted as a protective barrier against desiccation of arils and seeds. According to Sadeghi (2010), the aril ratio and juice yield are among pomegranate's most important traits. In Spanish varieties, the percentage of juice per fruit varies between $11 \%$

and $64 \%$, which is in agreement with the values reported in the present study.

The fruit's loss of moisture was also reflected in changes to its longitudinal and transverse diameters. These parameters decreased as storage time progressed, reaching over $18 \%$ reduction in longitudinal and more than $15 \%$ reduction in transverse diameter by the end of the storage period (Figures 2C and 2D). 


\section{Visual characteristics}

The external appearance of the fruits remained satisfactory until day 6 in the storage (Figure 3). After this period, the fruits developed damages and marked dryness, which can impair pomegranate's quality for sale in natura. The internal aspects of the fruit were satisfactory, with no visible alterations in aril succulence or color (Figure 4), indicating that the internal integrity of the fruit was maintained. This trait can be important in the processing of juice, because even if the juice is not extracted from fruits with satisfactory appearance, a good juice yield can be obtained from fruits that have been stored for up to 18 days (at $27^{\circ} \mathrm{C}$ and $28 \% \mathrm{RH}$ ).

Figure 3. External appearance in pomegranate 'Molar' stored under ambient conditions $\left(27^{\circ} \mathrm{C}, 28 \% \mathrm{RH}\right)$.

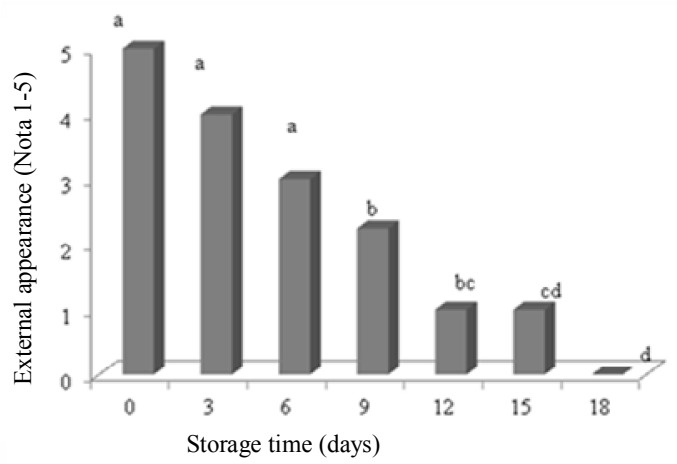

* Means followed by the same letter do not differ significantly according to Tukey's test at 5\% probability.

Figure 4. Internal appearance in pomegranate 'Molar' stored under ambient conditions $\left(27^{\circ} \mathrm{C}, 28 \% \mathrm{RH}\right)$.

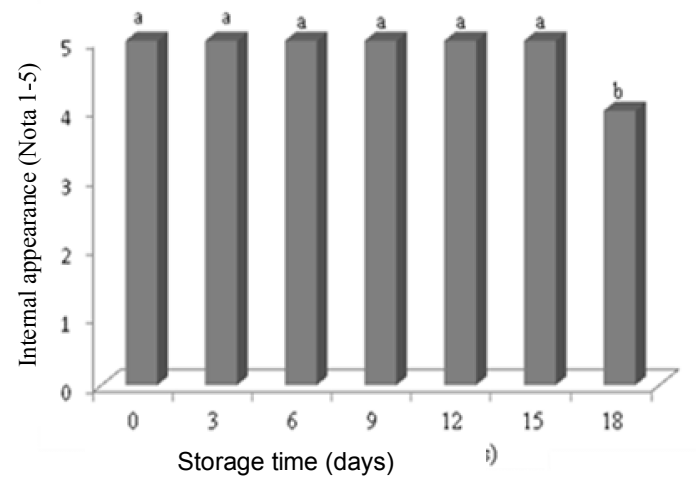

* Means followed by the same letter do not differ significantly according to Tukey's test at 5\% probability.

\section{Physical and chemical characteristics}

The pomegranate's TA increased from day zero to day 6 in storage, followed by a small decline and then by another small increase. However, the acidity levels of the Molar pomegranate were generally low, ranging from $0.60 \%$ to $0.70 \%$ of citric acid, which represents a narrow variation for this trait
(Figure 5A). In agreement with the low oscillations of titratable acidity, the juice $\mathrm{pH}$ in the fruits did not change during storage, averaging to $\mathrm{pH} 2.74$, without regression adjustments in this trait (Figure $5 B)$.

The pomegranate's organic acid composition varies between varieties (SERRANO, 2012). 
Varieties that are considered acidic pomegranates produce highly acidic fruits, with more than $2 \%$ acidity; bittersweet varieties produce low-acidic fruits, with 1-2\% acidity; and sweet pomegranates, have fruits with less than $1 \%$ acidity (ONUR; KASKA, 1985). Citric acid is predominant in the acidic varieties, whereas the acidity in sweet varieties is represented by balanced amounts of citric and malic acids, or in some instances, predominantly malic acid (SERRANO, 2012). Thus, according to the acidity levels registered during storage, Molar pomegranate is classified in the group of sweet pomegranate varieties, with less than $1 \%$ acidity.

Figure 5. Titratable acidity (A) and $\mathrm{pH}(\mathrm{B})$ in pomegranate 'Molar' stored under ambient conditions $\left(27^{\circ} \mathrm{C}, 28 \%\right.$ $\mathrm{RH})$.

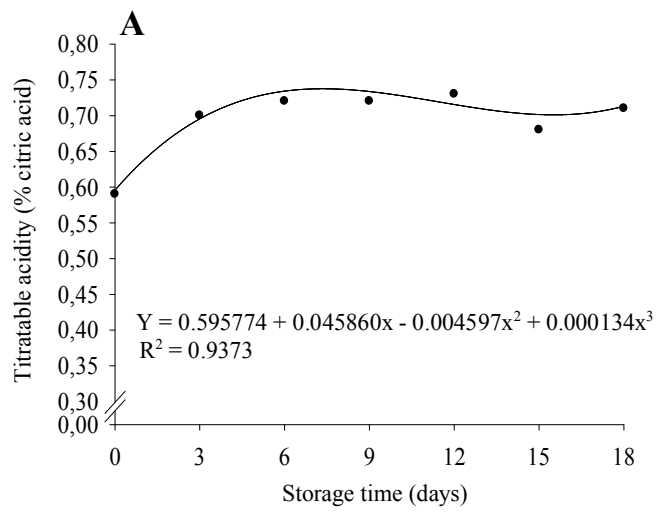

Silva (2011) reported the average levels of citric acid of $0.46 \%$ and $0.51 \%$ in Wonderful and Molar pomegranate varieties, respectively. Generally, according to Quiroz (2009), varieties with nitric acid levels below $0.9 \%$ are used mainly for in natura consumption, and varieties with nitric acid levels above $1 \%$ are more appropriate for the industry. Therefore, Molar pomegranate, produced in an organic system in the semi-arid region of Paraíba, possesses fruits of satisfactory qualities regarding the acidity for consumption of the fruit's arils in natura.

A variation of $12-15 \%$ soluble solids was recorded during storage, with quadratic effect, in which the lowest soluble solid content was reported on day 9 in storage. This effect was likely the result of small variations in the maturation stages of the fruits at the time of harvest, which could not have been perceived through the size and color criteria adopted for fruit selection (Figure 6A). The values obtained in this study for soluble solids are in

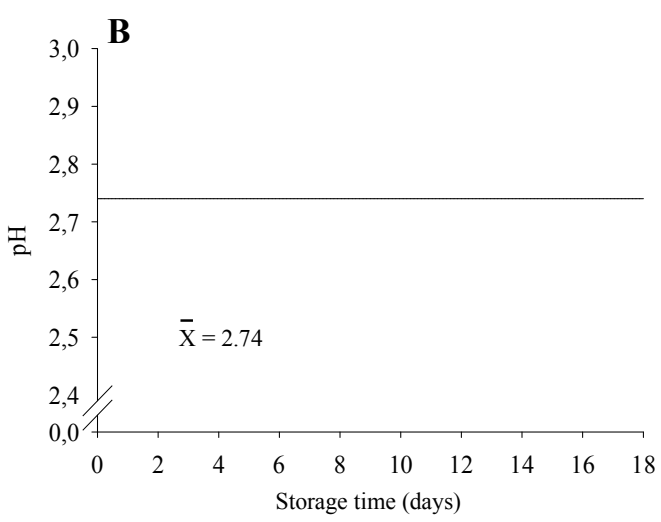

agreement with those indicated by Mirdehgha et al. (2007), who reported variations between $10 \%$ and $18 \%$, and with those of Martinez et al. (2010), who found $12.36-16.32 \%$ variation in soluble solids in Spanish pomegranate varieties.

The variation in vitamin $\mathrm{C}$ content had a cubic effect, with strong tendency to increase from day 3 to day 15 in storage (Figure 6B). A decline was then observed by day 18 that resulted from reduced metabolism and fruit senescence, accompanied by the intense loss of fruit's fresh mass, diameter, and acidity. The vitamin $\mathrm{C}$ values recorded during the course of this work are compatible to those registered by Küpper (1995) and Sayyari et al. (2010). According to Küpper (1995), pomegranates have low ascorbic acid content compared to many other fruits, ranging from 0.49 to $30 \mathrm{mg} 100 \mathrm{~g}^{-1}$ of juice. However, Sayyari et al. (2010) reported

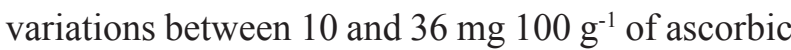
acid in pomegranate juice. 
Figure 6. Soluble solids (A), vitamin C (B), SS/AT (C) in pomegranate 'Molar' stored under ambient conditions (27 $\left.{ }^{\circ} \mathrm{C}, 28 \% \mathrm{RH}\right)$.
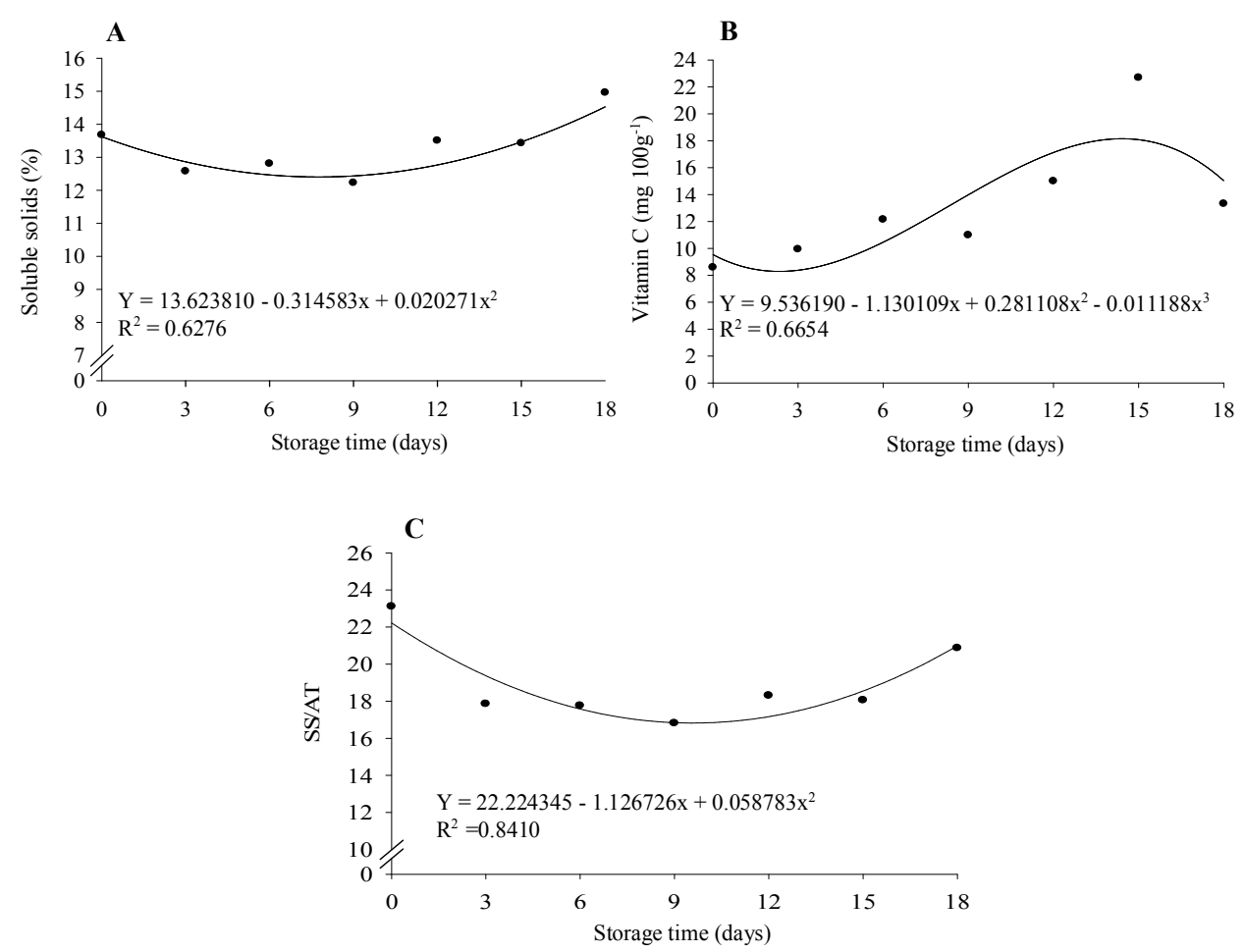

The SS/TA ratio had a quadratic effect during storage, behaving similar to the soluble solids, which indicates that the phenomena responsible for the alterations in soluble solids were also reflected on the SS/TA ratio, which varied between 12 and 15 (Figure 6C). The SS/TA ratio is an important indicator of pomegranate fruit maturation, with values that vary between 3.73 and 86.3 , depending on the maturation stage and pomegranate variety (FAWOLE; OPARA, 2013).

According to Chitarra and Chitarra (2005), the SS tend to increase as maturation progresses, whereas TA decreases as maturation progresses. For many fruits, the ratio between organic acids and sugars is used as an evaluation criterion for flavor.

\section{Conclusions}

Molar pomegranate produced in an organic system in the semi-arid region of Paraíba is classified as sweet, low in acidity, with less than $0.75 \%$ citric acid, and $12-15 \%$ soluble solids;

Regarding its size, the pomegranate is classified as small, weighing less than $200 \mathrm{~g}$ and being less than $74 \mathrm{~mm}$ in diameter.

Storing the pomegranate fruits at $27^{\circ} \mathrm{C}, 28 \%$ $\mathrm{RH}$ for up to 6 days maintains their biometric, visual, and physicochemical characteristics that are appropriate for the sale in natura;

Storing the fruits at $27^{\circ} \mathrm{C}, 28 \% \mathrm{RH}$ for 18 days results in an intense peel desiccation, but it does not diminish the quality or yield of the juice extracted from the arils.

\section{References}

AL-MAIMAN, S. A.; AHMAD, D. Changes in physical and chemical properties during pomegranate (Punica granatum L.) fruit maturation. Food Chemistry. Saudi Arabia, v. 76, n. 4, p. 437-441, 2002. 
CHITARRA, M. I. F.; CHITARRA, A. B. Pós-colheita de frutos e hortaliças: fisiologia e manuseio. Lavras: Editora UFLA, 2005, 785 p.

CRISOSTO, C. H.; MITCHAM, E. J.; KADER, A. A. Pomegranates. Perishables Handling, Califórnia, v. 85, n. 1, p. 17-18, 1996. Available at: <http://postharvest. ucdavis.edu>. Accessed at: 20 mar. 2014.

FAWOLE, O. A.; OPARA, U. L. Changes in physical properties, chemical and elemental composition and antioxidant capacity of pomegranate (cv. 'Ruby') fruit at five maturity stages. Scientia Horticulturae, v. 150, n.4, p. 37-46, 2013.

FRAGA, A. Os belos dotes da Wonderful. Revista Globo Rural. n. 329, p. 1-5, 2013. Disponível em: <http://www. evistagloborural.globo.com. Acesso em: 17 maio 2015.

INSTITUTO ADOLFO LUTZ - IAL. Normas analíticas do Instituto Adolfo Lutz: métodos fisico-químicos para análise de alimentos. 1. Edição digital. São Paulo: IAL, 2008. 1020 p. Disponível em: <http://www.ial.sp.gov. br>. Acesso em: 20 mar. 2014.

JADON, G.; NAINWANI, R.; SINGH, D.; SONI, P. K.; DIWAKER, A. K. Antioxidant activity of various parts of Punica granatum: a review. Journal of drug delivery \& therapeutics, Coden, v. 6, n. 2, p. 138-141, 2012.

KULKARNI, A. P.; ARADHYA, S. M. Chemical changes and antioxidant activity in pomegranate arils during fruit development. Food Chemistry, Saudi Arabia, v. 93, n. 2, p. 319-324, 2005.

KÜPPER, W. Wirkungen von temperatur und $\mathrm{CO}_{2}^{-}$ konzentration in der langfristigen $C A$ - lagerung auf verschiedene qualitaetsmerkmale und die respiration waehrend der nachlagerungsphase des granatapfels (Punica granatum L.) der sorte 'Hicaznar.' 1995. Tese (Pós-Doutorado) - Institut für Obstbau und Gemüsebau der Rheinschen Friedrich-Wilhelms- Akdeniz University, Bonn.

MARTINEZ, J. J.; MELAREJO, P.; HERNANDEZ, F.; SALAZAR, D.M.; MARTINEZ, R. Arils characterization of five new pomegranate (Punica granatum $\mathrm{L}$.) varieties. Scientia Horticulturae, v. 110, n. 3, p.241-246, 2010.
MIGUEL, G.; FONTES, C.; ANTUNES, D.; NEVES, A.; MARTINS, D. Anthocyanin concentration of 'Assaria' pomegranate fruits during different cold storage conditions. Journal of Biomedicine and Biotechnology, Faro, v. 5, n.5, p. 338-342, 2004.

MIRDEHGHA, S. H.; RAHEMI, M.; MARTINESROMERO, D.; GUILLEN, F.; VALVERDE, J. M.; ZAPATA, P. J.; SERRANO, M.; VALERO, D. Reduction of pomegranate chilling injury during storage after heat treatment: rob of polyamines. Postharvest Biology and Technology, Amsterdam, v. 44, p. 19-25, 2007.

ONUR, C.; KASKA, N. Akdeniz bölgesi narlarının (Punica granatum L.) seleksiyonu (Selection of Pomegranate of Mediterranean region). Turkish Journal Agricultural, Syria, v. 9, n. 3, p. 25-33, 1985.

OZGEN, M.; DURGAÇ, C.; SERÇE, S.; KAYA, C. Chemical and antioxidant properties of pomegranate cultivars grown in the Mediterranean region of Turkey. Food Chemistry, v. 111, n. 3, p. 703-706, 2008.

POYLAZOGLU, E.; GÖKMEN, V.; ARTIK, N. Organic acids and phenolic compoundsin pomegranates (Punica granatum L.) grown in Turkey. Journal of Food Composition and Analysis, Kidlington, v. 15, n. 5, p. 567575, 2002.

QUIROZ, I. Granados, perspectivas y oportunidades de un negocio emergente. Santiago: Fundación Chile, 2009. $65 \mathrm{p}$.

SADEGHI, H. Physical and chemical characteristics of four native pomegranate cultivars in Mazandaran province of Iran. Journal of Food, Agriculture \& Environment, Iran, v. 8, n. 2, p. 570-572, 2010.

SAYYARI, M.; VALERO, D.; BABALAR, M.; KALANTARI, S.; ZAPATA, P. J.; SERRANO, M. Prestorage oxalic acid treatment maintained visual quality, bioactive compounds, and antioxidant potential of pomegranate after long-term storage at $2{ }^{\circ} \mathrm{C}$. Journal of Agricultural and Food Chemistry, California, v. 58, n. 11, p. 6804-6808, 2010.

SERRANO, M. La Granada: maduración y postrecolección. I Jornadas Nacionales sobre el granado. Valencia, 2012. Available at: <http://www.poscosecha. com>. Accessed at: 22 mar. 2012.

SILVA, J. I. Romã orgânica: depoimento. Rio de Janeiro, 2011. (Entrevista concedida a Coordenadora OrganicsNet). Disponível em: <http://www.organicsnet. com.br/sobre >. Acesso em: 22 nov. 2011. 